Kansas State University Libraries

New Prairie Press

International Symposium for Innovative

Teaching and Learning
2017 International Symposium on Innovative Teaching and Learning

\title{
An Integrated English Language Program: Supporting University Internationalization
}

Ketty Reppert

Kansas State University, kreppert@ksu.edu

Smoky Kelly

Kansas State University, slkelly@ksu.edu

Leena Chakrabarti

Kansas State University, leena@ksu.edu

Follow this and additional works at: https://newprairiepress.org/isitl

Part of the Bilingual, Multilingual, and Multicultural Education Commons, Curriculum and Instruction Commons, Language and Literacy Education Commons, and the Scholarship of Teaching and Learning Commons

(1) 9

This work is licensed under a Creative Commons Attribution-Noncommercial-No Derivative Works 4.0 License.

\section{Recommended Citation}

Reppert, Ketty; Kelly, Smoky; and Chakrabarti, Leena (2017). "An Integrated English Language Program: Supporting University Internationalization," International Symposium for Innovative Teaching and Learning. https://doi.org/10.4148/2573-4911.1016

This Poster is brought to you for free and open access by the Conferences at New Prairie Press. It has been accepted for inclusion in International Symposium for Innovative Teaching and Learning by an authorized administrator of New Prairie Press. For more information, please contact cads@k-state.edu. 


\section{An Integrated English Language Program: Supporting}

University Internationalization

Smoky Kelly; Leena Chakrabarti; Ketty Reppert

Kansas State University, English Language Program, Office of International Programs

University Support and Services English Proficiency Test

\begin{tabular}{|l|l|}
\hline Offered at the beginning of every & $\begin{array}{c}\text { Administered in } \\
\text { 2016-2017 }\end{array}$ \\
\hline
\end{tabular}

\begin{tabular}{l|lr}
\hline semester & EPT & 381 \\
& &
\end{tabular} \begin{tabular}{l|ll} 
& \\
have not provided proof of English & J-1 & 135 \\
\cline { 2 - 3 } & SPEAK & 137
\end{tabular} Proficiency

English Assessment for J-1 Exchange Visitors

Offered on an as-needed basis year-round

Federal requirement of language

measurement for $\mathrm{J}-1$ visitors

SPEAK Tests for International Teaching

Offered monthly, with extra sessions

Review sessions and tutoring provided to

Board of Regents-mandated assessment

K-State 2025 Internationalization Overarching Goal:

"Infuse internationalization in all we do in order to ensure that K-State students, faculty, and staff are prepared to live, learn, and work in the global community."

\section{Partnerships and Initiatives}

Training for undergraduates in teaching ESL for summer-abroad programs at Wuhan University (China) and Selcuk University
(Turkey), 2004-2007 (OIP, Study Abroad, Community Service Abroad) Participation in World Bank Strengthening Higher Education
(SHEP) at Kabul and Balkh Universities, Afghanistan, 2007-2011 English course for participants from FATA of Pakistan, JanuaryFebruary and August- September, 2009 (College of Agriculture, Agricilture Manageme

- Practicum experiesce for MA TEFL degree in the department of

English language training for GoTeacher participants funded by of Education, Global Campus)

Technical Writing for SMASH Program, 2013-2015 (HanYang University, South Korea; Department of Computer Science; Global Campus)

Faculty Training Workshops at Universidad Central, Santiago Chile, funding from the Chilean Ministry of Higher Education April 2016 (ELP and O1P)

4-Week Program for Universidad Central students with funding

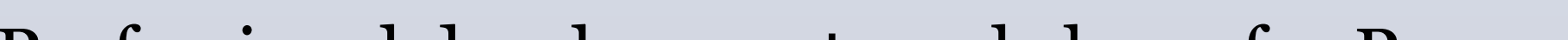
- Professional development workshops for Paraguayan English

sponsored by DIKTI, December 2016 (ELP and OIP)

English training to prepare students for Professional Pilots

program, 2017-2018 (Polytechnic Campus and Saudia Airlines)

English course to prepare students for study at the American

Institute of Baking, August 2017 (AIB)

JE-administered grant to train Brazilian English teachers,

January 2018 (ELP and OIP)

\section{English Language Program}

The mission of the English Language Program is to serve non-native speakers of English and the

university by:

offering a full range of intensive English classes,

assessing language proficiency,

developing special programs for short-term and exchange groups,

- orienting students to American culture and the academic environment,

- providing academic and personal advising, and

facilitating students' transition to degree programs through support courses

in the belief that the university community as well as the language learners will be enriched

through their participation at Kansas State University.

Number of Students by Country - Fall

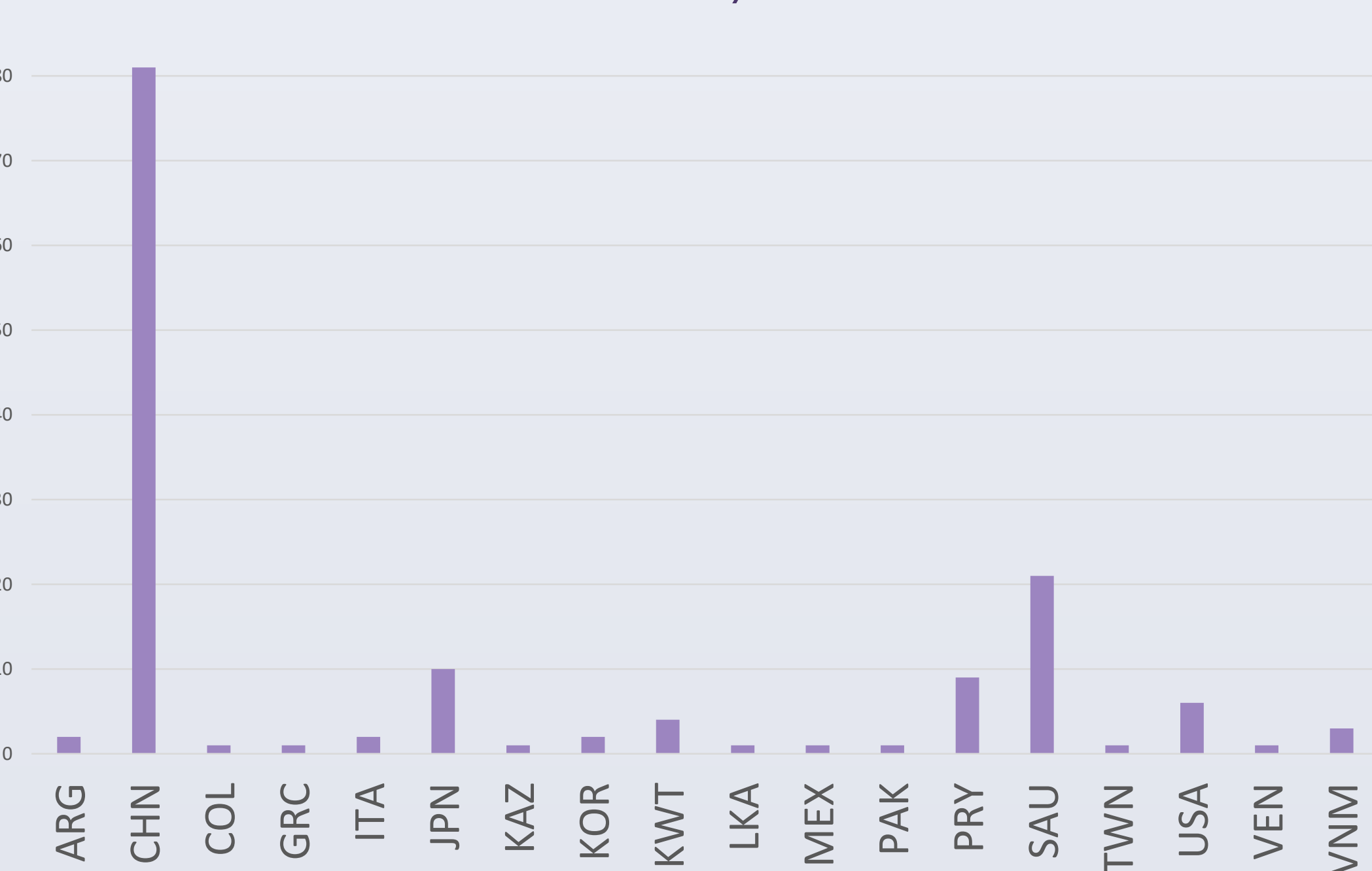

- 5 levels of English - Beginner to Advanced

prepares students to read, write, listen, and speak in academic the university

- Courses for degree-seeking and non-degree students

- Full-time ELP students enroll in 18 credit hours per semester

ELP classes carry undergraduate academic credit through the College of

Arts and Sciences (courses offered through the Dean's Office)

作

depending on the major

Advanced ELP classes fulfill K-State 8 requirements for Global Issues \&

Perspectives and Human Diversity within the U.S. Accredited by CEA

Academics

Bringing International Perspectives to the Classroom and Campus Community

Leadership Studies (Fall 2010-present)

ELP students participate in a LEAD 350 clas

Conversation Days with College of Business Administration (2012-present)

College of Business students come to our ELP classes to converse

niversity Experience (2014-present)

- SLP and University Experience students meet and are introduced Students meet again for recreation at a location they choose

KSDB FM Radio interviews (Summer 2016-Spring 2017)

Prepared questions and interviewed each other in pairs for the radio

Shared music from their home countries

Anthropology Activities with Dr. Wesch and students (Summer 2017) (D. Morgan, personal communication, September 19, 2017.)

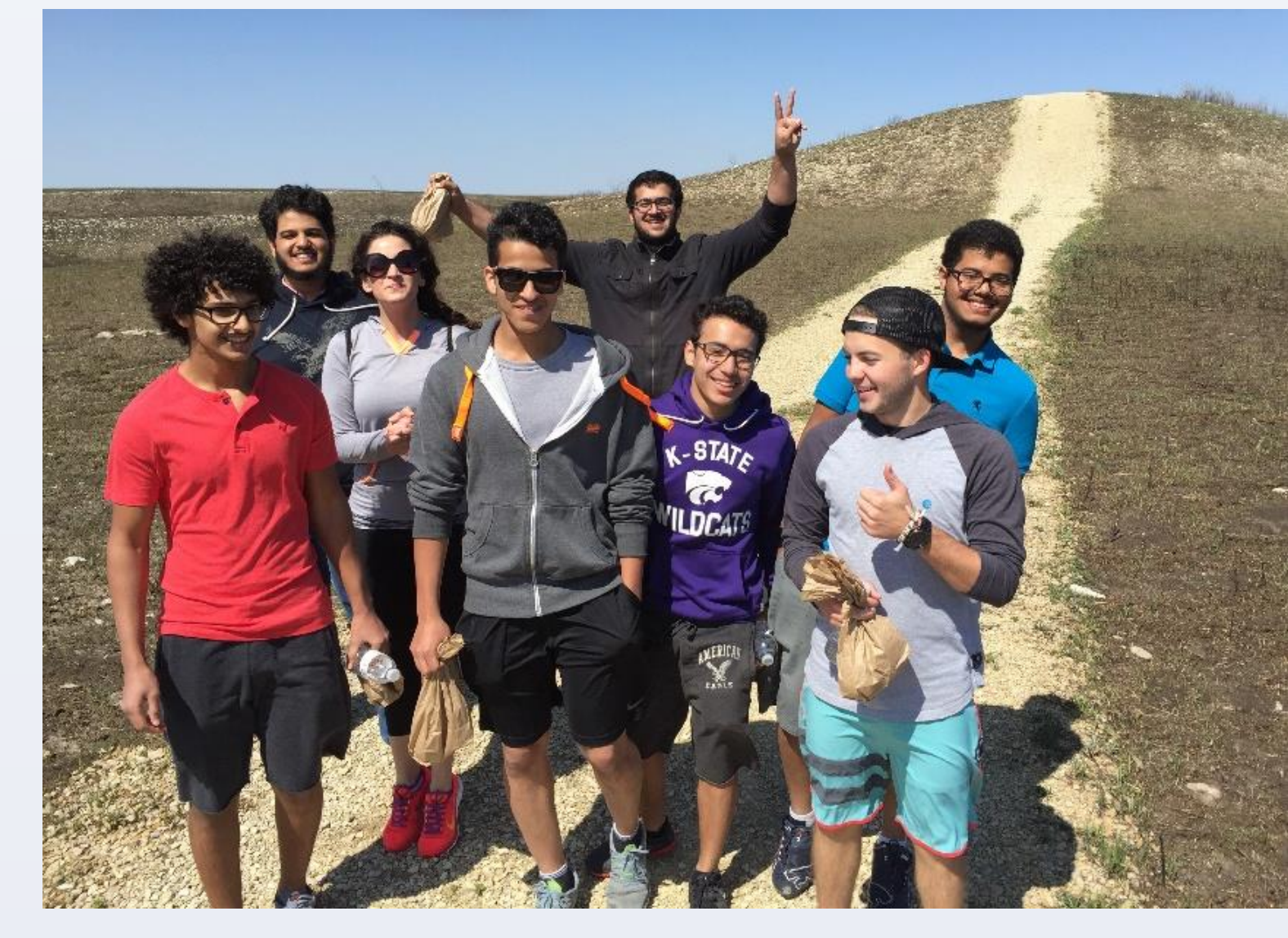

Began as a year-round program in the fall of 1986 with 38 student Initially housed in the Division of Continuing Education (Global Campus)

Since the 1990's, housed administratively under the Office of International Programs

Corses are now offered through the College of Arts and Sciences semester

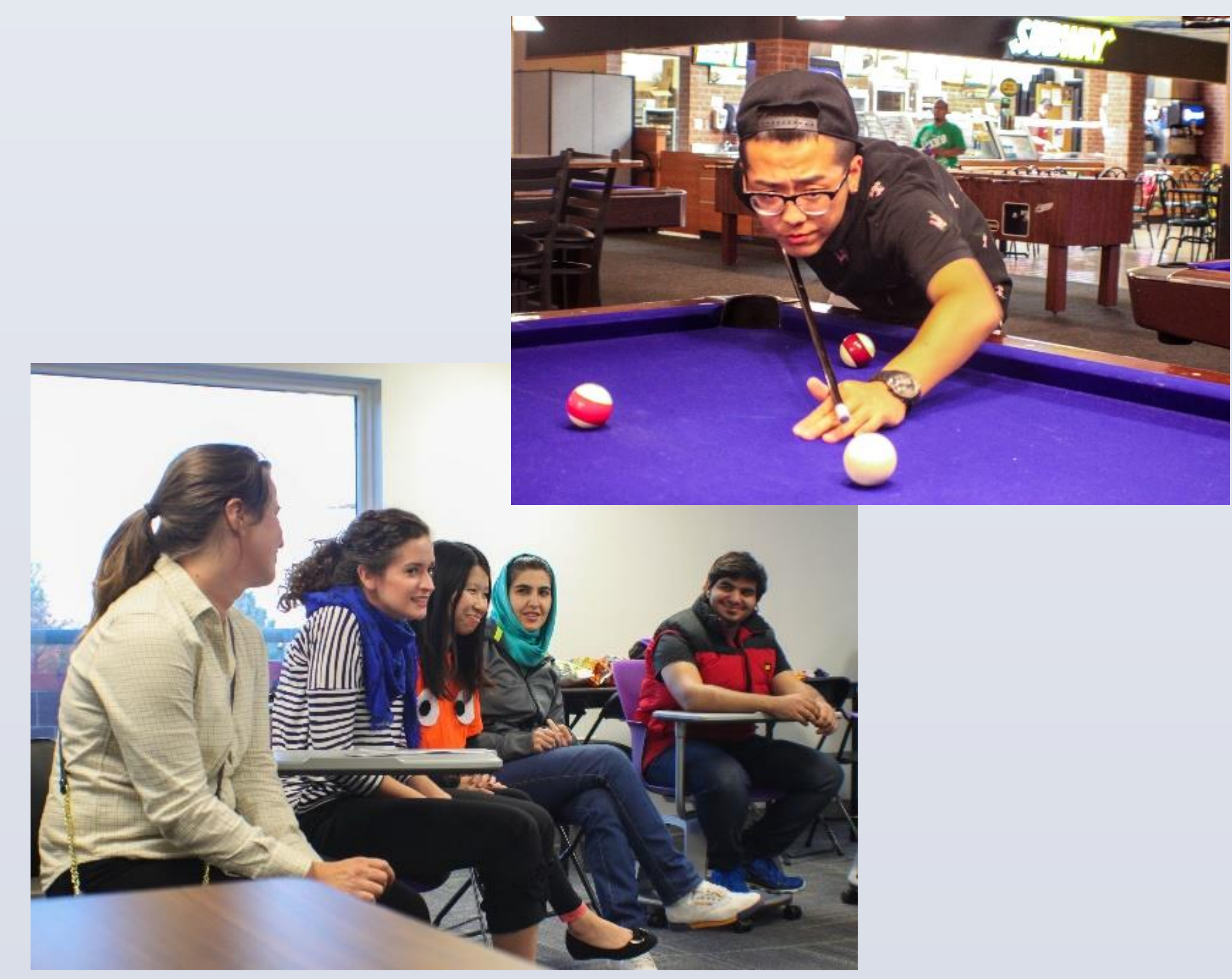

Encourage cross-cultural interaction between and among international and domestic students...

K-State 2025 Internationalization
Strategic Action Plan

Cultivate global and cross-cultural perspectives of our students, faculty, and staff through strategies such as: d) promoting international and cross-cultural events as a roulthe part of the K-State university experience. -State 2025 Internationalization Strategic Action Plan

Build a community that is receptive to internationa students, faculy, and visitors and expand outreach local communities and the state. K-State 2025 Internationalization Strategic
Action Plan

\section{Student Services}

Advising

- Appointment with an advisor for every new student

Follow-up appointments as needed and during DAS 158

Pre-Enrollment with advisors from students' majors during last

semester of ELP classes before students enter a degree program

Opportunities to audit university courses

- Social Hangout

Basic ELP Orientation - Beginning/Intermediate (DAS 148) Basic information such as ELP grading processes and services Presentations on plagiarism, motivation, and organizational skills

Orientation to the American Higher Education System -

dvanced (DAS 158)

- Emphasizes cultural and

- Develop a

- Topics include GPA and system, academic

integrity, legal issues,
career choices, stres

management, immigration regulations,
and travel in the U.S.

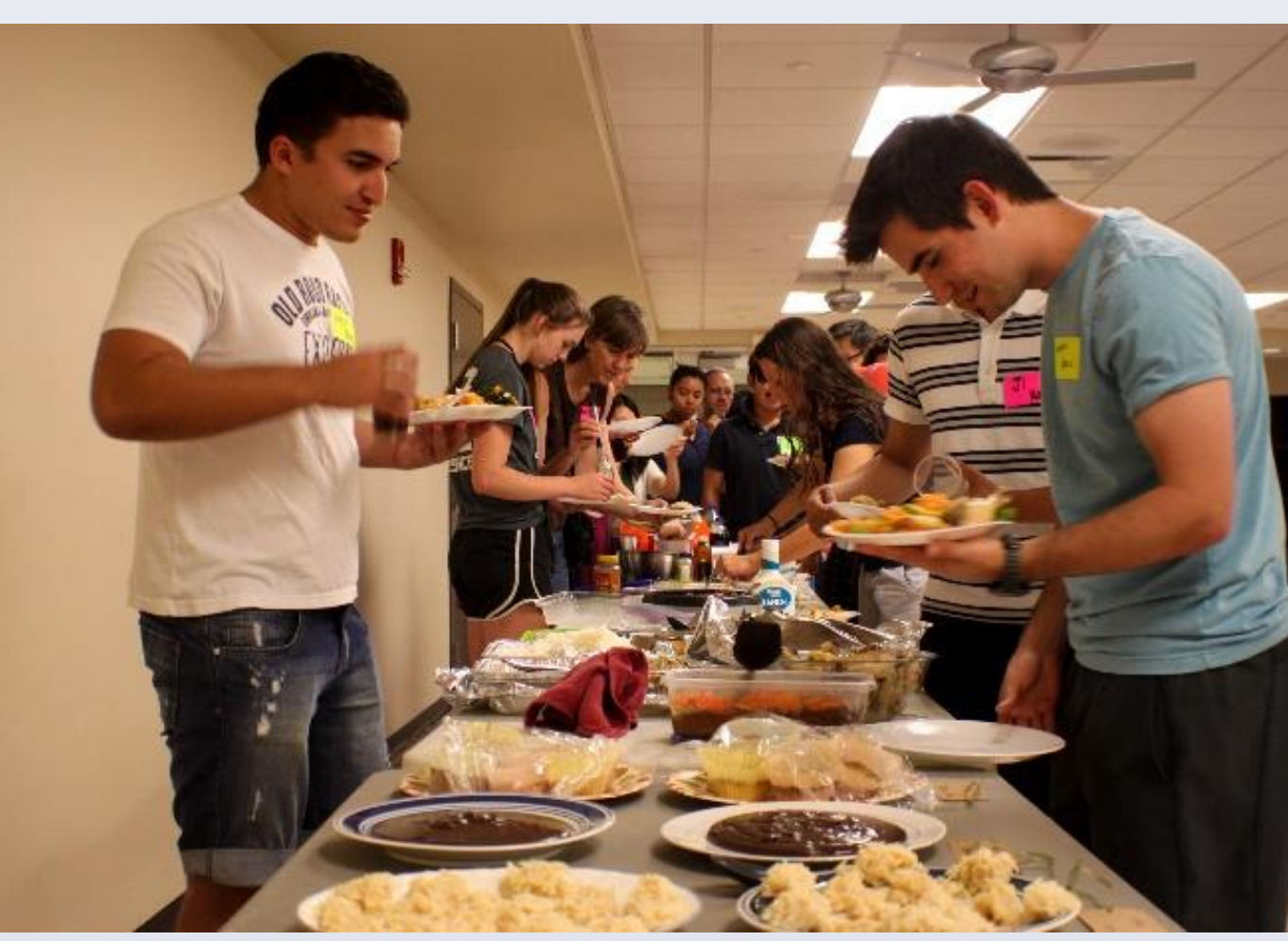

Recruit, retain, and increase the number of qualified

e) Develop, support, and resource effective transition
programs for international students expanding on the

programs or international students, expanding on
First Year Experience (FYE) concept. K-State 2025

Internationalization Action Plan

K-State 2025 Internationalization Strategic Action
Plan

pport Classes for Students in Need

- Study Skills classes for students on Probation (2 cr. hrs.)

IOWARD Class for Reinstated Students (DAS O32) - 2 cr. hrs. Training in Organization, Wellness, Academics, Responsibility and Discipline

Internation

(ITC)

intro to Mshops such as

Community involvement

lectures and TED-style

Testing and Tutorin

nter (TTC)

Individual tutoring

sessions

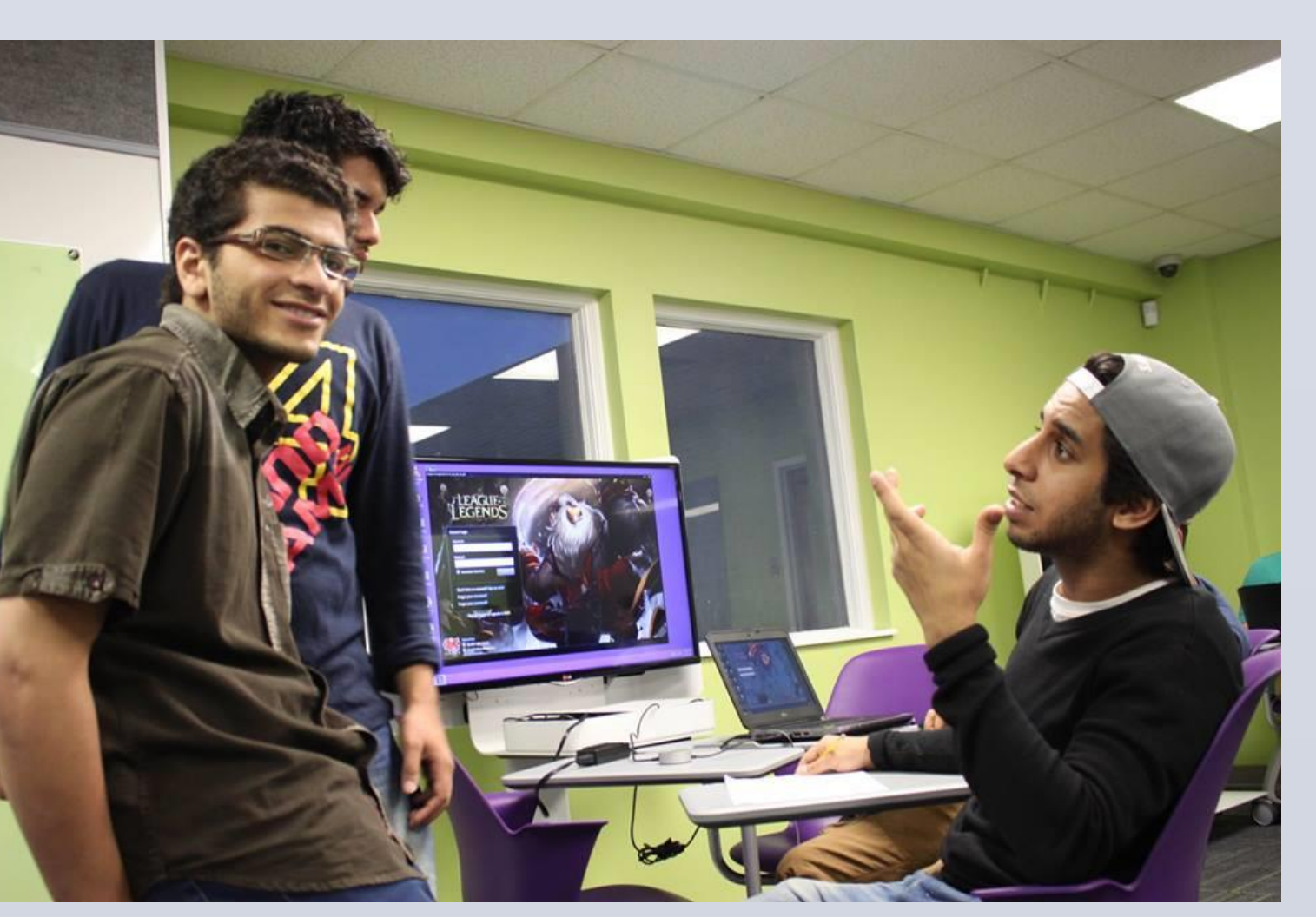

Sources

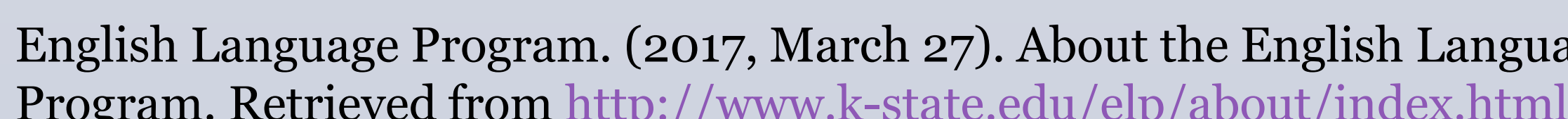
Kansas State University. (2017, August 17). Our Strategic Action Plans. Retrieved - Morgan, D., personal communication, September 19, 2017

Wood, M., email September 19, 2017. 